\title{
A NOTE ON TRANSLATIONS
}

The translations of the texts for Bach's oratorios are based on Michael Marissen, Bach's Oratorios. The Parallel GermanEnglish Texts with Annotations (Oxford: Oxford University Press, 2008). Translations of texts from Bach's cantatas follow Alfred Dürr, The Cantatas of J. S. Bach, trans. Richard D. P. Jones (Oxford: Oxford University Press, 2005). All other translations (especially of theological texts from the seventeenth and eighteenth centuries) are mine unless stated otherwise. 
